\title{
EFEKTIFITAS EKSTRAK DAUN SUKUN HASIL PEREBUSAN TERHADAP PERTUMBUHAN KOLONI BAKTERI STREPTOCOCCUS MUTANS
}

\author{
Sariyem $^{\varpi 1}$, Sadimin $^{2}$, Lanny Sunarjo $^{3}$, Makhyatun Haniyati $^{4}$
}

\begin{abstract}
ABSTRAK
Senyawa flavonoid daun sukun berkhasiat sebagai antimikroba berfungsi membunuh atau menghambat pertumbuhan mikroorganisme. Daun sukun juga mengandung senyawa lain yaitu saponin, polifenol, tanin, asam hidrosianat, asetilkolin, riboflavin, dan fenol. Tujuan penelitian mengetahui efektifitas ekstrak daun sukun hasil perebusan terhadap pertumbuhan koloni bakteri Streptococcus Mutans.

Jenis penelitian menggunakan metode eksperimen. Dalam penelitian ini yang diteliti adalah pertumbuhan koloni bakteri Streptococcus mutans sebelum dan sesudah diberi ekstrak daun sukun hasil perebusan dengan konsentrasi 10\%,20\%,40\%,60\%. Rancangan penelitian yang dilakukan adalah pre-test-posttest with control group. Pada penelitian ini dilakukan 2 kali pengulangan.

Hasil penelitian menunjukkan bahwa ekstrak daun sukun efektif menghambat pertumbuhan koloni bakteri Streptococcus mutans. Ekstrak daun sukun hasil perebusan pada konsentrasi $60 \%$ paling efektif menghambat pertumbuhan koloni bakteri Streptococcus mutans dibandingkan konsentrasi 10\%, 20\%, 40\%. Senyawa kimia yang terkandung dalam daun sukun yaitu polifenol yang mempunyai khasiat sebagai antimikroba terhadap bakteri dan jamur. Tidak hanya itu, daun sukun juga mengandung senyawa flavonoid yang memiliki khasiat dahsyat sebagai antimikroba. Flavonoid merupakan golongan polifenol sehingga memiliki sifat kimia senyawa fenol yaitu bersifat agak asam sehingga dapat larut dalam basa. Flavonoid juga memiliki gugus hidroksil sehingga pada umumnya larut dalam pelarut polar seperti etanol, methanol, butanol, aseton, dan air.
\end{abstract}

Kata kunci : Ekstrak Daun Sukun, Streptococcus mutans

\begin{abstract}
Breadfruit leaf flavonoid compounds useful as antimicrobial function kill or inhibit the growth of microorganisms. Breadfruit leaves also contain other compounds, namely saponins, polyphenols, tannins, hydrocyanic acid, acetylcholine, riboflavin, and phenols The aim of research was effectiveness results boiling breadfruit leaf extract on growth colony of bacteria Streptococcus mutans.

This type of research used experimental method or experimental. In this research study is the growth of Streptococcus mutans bacteria colony before and after given the results boiling breadfruit leaf extract at a concentration of 10\%, 20\%, 40\%, 60\%. The design of the research is a pre-test-post-test with control group. In this research used two repetitions.

The results of the research show that breadfruit leaf extract effectively inhibits the growth of bacterial colonies of Streptococcus mutans. Results boiling breadfruit leaf extract at a concentration of $60 \%$ of the most effective at inhibiting the growth of Streptococcus mutans bacteria colony than the concentration of 10\%, 20\%, $40 \%$. Chemical compounds contained in the leaves of breadfruit namely polyphenols which have properties as an antimicrobial against bacteria and fungi. Not only that, the breadfruit leaf also contains flavonoids that have powerful antimicrobial properties. An antimicrobial agent serves to kill or inhibit the growth of microorganisms. Flavonoids are polyphenolic compounds that have chemical properties that are slightly acidic phenols that can be dissolved in alkaline. Flavonoids are also contains hydroxyl groups that are generally soluble in polar solvents such as ethanol, methanol, butanol, acetone, and water.
\end{abstract}

Key words : Breadfruit Leaf Extract, Streptococcus mutans

1,2,3) Dosen Jurusan Keperawatan Gigi Poltekkes Kemenkes Semarang

4) Mahasiswa Jurusan Keperawatan Gigi Poltekes Kemenkes Semarang

: Sariyemjkg@gmail.com 


\section{PENDAHULUAN}

Masalah utama kesehatan gigi dan mulut pada masyarakat Indonesia adalah keadaan kebersihan mulut yang pada umumnya kurang memenuhi syarat kesehatan sehingga menyebabkan tingginya prevalensi penyakit gigi dan mulut (Depkes RI, 2009). Penyakit gigi dan mulut terutama karies dan penyakit periodontal masih banyak diderita baik anak-anak maupun usia dewasa (Hiranya,dkk, 2011). Di Indonesia laporan Riset Kesehatan Dasar (RISKESDAS) tahun 2007 menyatakan, prevalensi karies aktif mencapai $46,5 \%$ penduduk, dimana prevalensi pengalaman karies mencapai $72,1 \%$ penduduk. Sedangkan prevalensi karies aktif di provinsi Jawa Tengah sebesar 43,1\%, dan pengalaman karies sebesar $67,8 \%$.

Karies gigi merupakan suatu penyakit jaringan keras gigi yaitu enamel, dentin dan sementum, yang disebabkan oleh aktivitas suatu jasad renik pada suatu karbohidrat yang diragikan dan ditandai adanya demineralisasi jaringan keras gigi (Koerniati, 2006). Untuk terjadinya karies, ada 3 faktor yang harus ada secara bersama-sama. Ketiga faktor tersebut adalah tersedianya bahan nutrisi untuk mendukung pertumbuhan bakteri, permukaan gigi yang rentan dan bakteri kariogenik.

Bakteri Streptococcus mutans dianggap sebagai organisme yang penting didalam mengawali terbentuknya karies gigi (Hiranya dkk, 2011). Bakteri spesifik inilah yang mengubah glukosa dan karbohidrat pada makanan menjadi asam melalui proses fermentasi (Pratiwi, 2007). Sisa makanan terutama yang mengandung gula 'sukrosa' merupakan makanan utama Streptococcus mutans untuk tumbuh dan berkembang biak. Akibatnya, gigi akan menjadi rapuh dan mudah berlubang. Jika tidak segera ditangani secara tepat, kerusakan bisa menjalar ke rongga lebih dalam dari bagian gigi, yaitu dentin dan pulpa. Jika sudah melukai pulpa membutuhkan perawatan lebih kompleks (Djamil, 2011). Pencegahan karies gigi salah satunya dengan rajin menjaga kesehatan gigi dan mulut yang baik, sehingga dapat menyingkirkan akumulasi bakteri dari gigi (Pelczar dan Chan, 2008). Untuk menghambat atau mengurangi aktivitas mikroba patogen tersebut diperlukan zat antimikroba. Zat antimikroba berfungsi membunuh atau menghambat pertumbuhan mikroorganisme (Rizema, 2013). Senyawa antimikroba dari bahan alami antara lain flavonoid, minyak atsiri, saponin, polifenol yang banyak terdapat dalam tanaman obat (Rizema, 2013).

Daun sukun dimanfaatkan masyarakat kita untuk pengobatan penyakit seperti rematik, diabetes, radang sendi, hipertensi, sariawan, sakit gigi, liver, hepatitis, dan gangguan ginjal (Mardiana, 2013). Daun sukun mengandung senyawa yang memiliki khasiat dahsyat dalam menyembuhkan penyakit. Senyawa itu adalah flavonoid. Senyawa flavonoid daun sukun berkhasiat sebagai antimikroba berfungsi membunuh atau menghambat pertumbuhan mikroorganisme. Senyawa flavonoid daun sukun juga memiliki beberapa khasiat bagi kesehatan yaitu sebagai antiinflamasi, antioksidan, antiplatelet, antikanker, antidiabetes, dan antiatherosklerosis (Rizema, 2013). Daun sukun juga mengandung senyawa lain yaitu saponin, polifenol, tanin, asam hidrosianat, asetilkolin, riboflavin, dan fenol (Wardany, 2012).

\section{METODE PENELITIAN}

Penelitian ini menggunakan metode eksperimen atau percobaan (experimental research). Dalam penelitian ini yang diteliti adalah pertumbuhan koloni bakteri streptococcus mutans sebelum dan sesudah diberi ekstrak daun sukun hasil perebusan dengan konsentrasi 10\%, 20\%, 40\%, $60 \%$. Rancangan penelitian yang dilakukan adalah pre-test-post-test with control group yaitu dilakukan dua perlakuan, perlakuan sebelum penelitian dan sesudah penelitian 
(Notoatmodjo, 2010). Pada penelitian ini dilakukan 2 kali pengulangan.

Cara Pembuatan ekstrak daun sukun hasil perebusan :

Daun sukun yang akan digunakan dikeringkan kemudian dibuat serbuk, ditimbang sebanyak 10 gram ditambah 100 $\mathrm{ml}$ aquades dan menambahkan aquades sebanyak 2 kali berat serbuk $(10 \mathrm{ml} \times 2=$ 20ml). Penyaringan dilakukan selama 15 menit terhitung mulai suhu mencapai $90^{\circ} \mathrm{C}$ sambil sesekali diaduk, selanjutnya disaring melalui kain flannel dan memasukkannya kedalam gelas ukur (Nurani, 2012).

Cara membuat konsentrasi ekstrak daun sukun hasil perebusan :

Volume Zat terlarut $=\underline{\text { Konsentrasi ekstrak x Vol. Larutan }}$ $100 \%$

Vol pelarut $=$ vol.larutan - vol. zat terlarut $\quad($ Yazid, 2005 $)$

Cara Penghitungan koloni bakteri :

Pertumbuhan jasad renik dapat ditentukan secara kuantitatif dengan metode langsung maupun tidak langsung. Pengukuran pertumbuhan secara langsung dapat dilakukan dengan bermacam-macam cara, misalnya dengan menghitung jumlah sel menggunakan Petroff Hausser Bacteria Counter atau Hemasitometer, atau dengan mengukur kepekatan selnya menggunakan spektrofotometer. Jumlah sel dapat dihitung secara langsung jika jasad renik tersebut ditumbuhkan dalam medium cair. Dalam perhitungan secara langsung semacam ini, yang terhitung adalah jumlah total jasad renik yang masih hidup maupun yang sudah mati. Pertumbuhan dapat juga ditentukan secara tidak langsung, misalnya dengan metode penuangan pada medium padat, atau dengan menimbang berat biomassanya. Dalam metode penuangan, jumlah sel ditentukan dengan menghitung jumlah koloni yang tumbuh dalam medium padat sehingga yang terhitung hanya sel-sel yang masih hidup (Yuwono, 2010).

Soesanto (2011) menyebutkan bahwa metode Total Plate count adalah metode yang digunakan untuk menghitung bakteri maupun jamur. Media yang digunakan padat seperti NA, PCA, PDA, cara menghitungnya dengan manual.

\section{Metode Ekstraksi}

Nurani (2012) menyebutkan bahwa ekstraksi adalah kegiatan penarikan kandungan kimia yang dapat larut sehingga terpisah dari bahan yang tidak dapat larut dengan pelarut cair. Simplisia yang diekstrak mengandung senyawa aktif yang dapat larut dan senyawa yang tidak dapat larut seperti serat, karbohidrat, protein dan lain-lain. Senyawa aktif yang terdapat dalam berbagai simplisia dapat digolongkan ke dalam golongan minyak atsiri, alkaloid, flavonoid dan lain-lain.

Ekstrak daun sukun hasil perebusan dibuat dengan metode Infundasi. Infundasi merupakan metode penyaringan dengan cara menyaring simplisia dalam air pada suhu $90^{\circ} \mathrm{C}$ selama 15 menit. Infundasi merupakan penyaringan yang umum dilakukan untuk menyaring zat kandungan aktif yang larut dalam air dari bahan-bahan nabati. Infusa adalah hasil proses ekstraksi dengan menggunakan metode infundasi. Cara ini sangat sederhana dan sering digunakan oleh perusahaan obat tradisional. Dengan beberapa modifikasi, cara ini sering digunakan untuk membuat ekstrak.

Prosedur pembuatan infusa :

a. Simplisia yang berupa tanaman dengan derajat halus tertentu ditimbang (misalnya $10 \mathrm{~g})$, kemudian aquades $100 \mathrm{cc}$ dimasukkan kedalam panci atas. Menambahkan aquades sebanyak $2 x$ berat serbuk.

b. Setelah panci atas siap untuk diproses, maka masukkan panci beserta isinya segera ke dalam panci bawah yang telah berisi air. Setelah itu panci bawah dipanaskan di atas api langsung dan dibiarkan sampai mendidih (artinya suhu mencapai $100^{\circ} \mathrm{C}$ ). Diharapkan maka suhu air di panci bagian atas akan mencapai $90^{\circ} \mathrm{C}$. 
c. Pemanasan dilakukan selama 15 menit terhitung mulai air di panci bawah mendidih (suhu panci atas mencapai $90^{\circ} \mathrm{C}$ ), sambil sekali-sekali diaduk.

d. Setelah cukup 15 menit, maka panci atas diturunkan dan disaring selagi masih panas melalui kain flanel.

e. Apabila ternyata volume akhir yang didapat kurang dari 100cc (air semula $100 \mathrm{cc})$ maka perlu ditambahkan air panas secukupnya melalui ampas hingga diperoleh volume infusa yang dikehendaki yaitu $100 \mathrm{cc}$.

f. Cara menambahkan air itu harus menurut aturan kuantitatif, yaitu hasil saringan tadi dipindahkan ke gelas ukur, kemudian kekurangan air yang diperlukan, ditambahkan sampai volume akhir mencapai batas skala $100 \mathrm{cc}$ (jadi tidak boleh mengukur air sesuai dengan kurangnya air, namun yang diukur adalah bagian air yang akan ditambah) (Nurani, 2012).

\section{HASIL DAN PEMBAHASAN}

Berdasarkan pengambilan data yang dilakukan di Laboratorium Mikrobiologi diperoleh hasil sebagai berikut :

Tabel 1. Pertumbuhan Koloni Bakteri

Streptococcus Mutans sebelum perlakuan dan setelah perlakuan serta selisih pertumbuhan pada pengulangan 1

\begin{tabular}{cccc}
\hline \multirow{2}{*}{ Konsentrasi } & $\begin{array}{c}\text { Sebelum } \\
\text { Perlakuan }\end{array}$ & $\begin{array}{c}\text { Setelah } \\
\text { Perlakuan }\end{array}$ & Selisih \\
\hline $10 \%$ & $7,0 \times 10^{5}$ & $5,5 \times 10^{5}$ & $1,5 \times 10^{5}$ \\
\hline $20 \%$ & $7,0 \times 10^{5}$ & $4,2 \times 10^{5}$ & $2,8 \times 10^{5}$ \\
\hline $40 \%$ & $7,0 \times 10^{5}$ & $3,2 \times 10^{5}$ & $3,8 \times 10^{5}$ \\
\hline $60 \%$ & $7,0 \times 10^{5}$ & $2,5 \times 10^{5}$ & $4,5 \times 10^{5}$ \\
\hline
\end{tabular}

Berdasarkan Tabel 1 menunjukkan ekstrak daun sukun hasil perebusan dengan konsentrasi $60 \%$ paling efektif menghambat pertumbuhan koloni bakteri streptococcus mutans. Pada Konsentrasi $60 \%$ jumlah koloni bakteri streptococcus mutans yang awalnya $7,0 \times 10^{5} \mathrm{koloni} / \mathrm{ml}$ berubah menjadi
$2,5 \times 10^{5} \mathrm{koloni} / \mathrm{ml}$. Hal ini menunjukkan bahwa ekstrak daun sukun hasil perebusan dapat menghambat pertumbuhan koloni paling banyak $4,5 \times 10^{5}$ koloni $/ \mathrm{ml}$. Sedangkan untuk konsentrasi terendah $10 \%$ menjadi 5,5 x $10^{5}$ koloni $/ \mathrm{ml}$, hal ini menunjukkan bahwa ekstrak daun sukun hasil perebusan dapat menghambat pertumbuhan koloni paling sedikit $1,5 \times 10^{5}$ koloni/ml.

Tabel 2. Pertumbuhan Koloni Bakteri Streptococcus mutans sebelum perlakuan dan setelah perlakuan serta selisih pertumbuhan pada pengulangan 2

\begin{tabular}{cccc}
\hline Konsentrasi & $\begin{array}{c}\text { Sebelum } \\
\text { Perlakuan }\end{array}$ & $\begin{array}{c}\text { Setelah } \\
\text { Perlakuan }\end{array}$ & Selisih \\
\hline $10 \%$ & $7,0 \times 10^{5}$ & $5,4 \times 10^{5}$ & $1,6 \times 10^{5}$ \\
\hline $20 \%$ & $7,0 \times 10^{5}$ & $4,1 \times 10^{5}$ & $2,9 \times 10^{5}$ \\
\hline $40 \%$ & $7,0 \times 10^{5}$ & $3,1 \times 10^{5}$ & $3,9 \times 10^{5}$ \\
\hline $60 \%$ & $7,0 \times 10^{5}$ & $2,4 \times 10^{5}$ & $4,6 \times 10^{5}$ \\
\hline
\end{tabular}

Berdasarkan Tabel diatas dapat menunjukkan ekstrak daun sukun hasil perebusan dengan konsentrasi $60 \%$ paling efektif menghambat pertumbuhan koloni bakteri streptococcus mutans dibandingkan konsentrasi 10\%, 20\%, 40\%, karena dengan konsentrasi $60 \%$ menjadikan jumlah koloni bakteri streptococcus mutans yang awalnya $7,0 \times 10^{5} \mathrm{koloni} / \mathrm{ml}$ menjadi $2,4 \times 10^{5}$ koloni/ml, hal ini menunjukkan bahwa ekstrak daun sukun hasil perebusan dapat menghambat pertumbuhan koloni paling banyak 4,6 x $10^{5} \mathrm{koloni} / \mathrm{ml}$. Sedangkan untuk konsentrasi terendah $10 \%$ menjadi $5,4 \times 10^{5}$ koloni/ml, hal ini menunjukkan bahwa ekstrak daun sukun hasil perebusan dapat menghambat pertumbuhan koloni paling sedikit $1,6 \times 10^{5} \mathrm{koloni} / \mathrm{ml}$.

Tabel 3. Selisih pertumbuhan koloni bakteri Streptococcus Mutans pada pengulangan 1 dan 2

\begin{tabular}{lcccc}
\hline \multirow{2}{*}{ Pengulangan } & \multicolumn{4}{c}{ Konsentrasi } \\
& $10 \%$ & $20 \%$ & $40 \%$ & $60 \%$ \\
\hline Pengulangan 1 & $1,5 \times 10^{5}$ & $2,8 \times 10^{5}$ & $3,8 \times 10^{5}$ & $4,5 \times 10^{5}$ \\
\hline Pengulangan 2 & $1,6 \times 10^{5}$ & $2,9 \times 10^{5}$ & $3,9 \times 10^{5}$ & $4,6 \times 10^{5}$ \\
\hline Rata- rata & $1,6 \times 10^{5}$ & $2,9 \times 10^{5}$ & $3,9 \times 10^{5}$ & $4,6 \times 10^{5}$ \\
\hline
\end{tabular}


Berdasarkan Tabel diatas dapat dilihat bahwa daya hambat terbesar terjadi pada konsentrasi $60 \%$ karena dapat menghambat pertumbuhan koloni bakteri Streptococcus mutans sebanyak 4,6 × $10^{5}$ koloni/ml, sedangkan konsentrasi 20\% dapat menghambat pertumbuhan koloni bakteri yaitu $2,9 \times 10^{5} \mathrm{koloni} / \mathrm{ml}$, konsentrasi $40 \%$ dapat menghambat pertumbuhan koloni bakteri yaitu $3,9 \times 10^{5} \mathrm{koloni} / \mathrm{ml}$ dan pada konsentrasi $10 \%$ dapat menghambat pertumbuhan koloni paling sedikit yaitu 1,6 x $10^{5} \mathrm{koloni} / \mathrm{ml}$.

Berdasarkan hasil penelitian menunjukkan bahwa ekstrak daun sukun efektif menghambat pertumbuhan koloni bakteri Streptococcus mutans. Ekstrak daun sukun hasil perebusan pada konsentrasi $60 \%$ paling efektif menghambat pertumbuhan koloni bakteri streptococcus mutans dibandingkan konsentrasi 10\%, 20\%, 40\%, karena dengan konsentrasi $60 \%$ dapat menghambat pertumbuhan koloni paling banyak yaitu $4,5 \times 10^{5} \mathrm{koloni} / \mathrm{ml}$ dan konsentrasi terendah $10 \%$ dapat menghambat pertumbuhan koloni paling sedikit yaitu 1,5 x $10^{5} \mathrm{koloni} / \mathrm{ml}$. Hal ini disebabkan daun sukun memiliki kandungan kimia antara lain saponin, polifenol, asam hidrosianat, kalium, asetilcolin, tanin, riboflavin, dan phenol. Daun tanaman tersebut juga mengandung quercetin, champorol dan artoindonesianin. Quercetin dan artoindonesianin adalah kelompok senyawa dari flavonoid (Mardiana, 2013Zat antimikroba berfungsi membunuh atau menghambat pertumbuhan mikroorganisme (Rizema, 2013).

Flavonoid merupakan golongan polifenol sehingga memiliki sifat kimia senyawa fenol yaitu bersifat agak asam sehingga dapat larut dalam basa. Flavonoid juga memliki gugus hidroksil sehingga pada umumnya larut dalam pelarut polar seperti etanol, methanol, butanol, aseton, dan air (Dewanti dan Wahyudi, 2011).

Salah satu faktor yang mempengaruhi keberhasilan penelitian ini adalah kualitas ekstrak daun sukun yang digunakan. Ekstrak daun sukun yang digunakan dalam penelitian ini diekstraksi menggunakan metode infundasi, yaitu suatu metode ekstraksi dengan pelarut air pada temperature penangas air $\left(90^{\circ} \mathrm{c}\right)$, selama 15 menit. Metode tersebut umumnya digunakan untuk mengekstraksi zat aktif bahan-bahan nabati yang larut dalam air dan metode infundasi juga mudah diterapkan dalam masyarakat serta waktu yang dibutuhkan membuatnya cukup singkat (Nurani, 2012).

Kandungan flavonoid dalam ekstrak daun sukun menunjukkan bahwa ada hubungan yang positif antara kandungan flavonoid dengan kandungan fenolik dari pelarut yang digunakan untuk mengekstraksi daun sukun. Hal ini disebabkan senyawa flavonoid bersifat polar sehingga daun sukun yang terlarut pada air lebih banyak. Komponen fenolik seperti flavonoid yang dikenal sebagai antioksidan primer dari tanaman bersifat polar (Suryanto dan Wehantouw, 2009). Mekanisme kerja flavonoid dengan mendenaturasikan molekul-molekul protein dan asam nukleat yang menyebabkan koagulasi dan pembekuan protein yang akhirnya akan terjadi gangguan metabolisme dan fungsi fisiologis bakteri. Jika metabolisme bakteri terganggu maka kebutuhan energi tidak tercukupi sehingga mengakibatkan rusaknya sel bakteri secara permanen yang pada akhirnya menyebabkan kematian bakteri (Sabir, 2003).

Menurut Pelczar dan Chan (2008) mengatakan bahwa semakin tinggi konsentrasi antibakteri yang digunakan, maka semakin besar kemampuan dalam membunuh atau menghambat pertumbuhan bakteri. Hal ini disebabkan karena kemampuan daya bunuh atau daya hambat suatu bahan antimikroba dipengaruhi oleh banyak faktor diantaranya adalah faktor konsentrasi. Adapun hambatan pada penelitian ini adalah penghitungan koloni bakteri Streptococcus mutans yang masih dalam jumlah ratusan sehingga menyulitkan dalam menghitung. 


\section{KESIMPULAN}

1. Ekstrak daun sukun hasil perebusan efektif menghambat pertumbuhan koloni bakteri Streptococcus mutans. Semakin tinggi konsentrasi ekstrak daun sukun hasil perebusan maka semakin besar kemampuan dalam menghambat pertumbuhan koloni bakteri Streptococcus mutans

2. Ekstrak daun sukun hasil perebusan yang paling efektif terhadap pertumbuhan koloni bakteri streptococcus mutans yaitu konsentrasi $60 \%$ karena dapat menghambat pertumbuhan koloni bakteri paling banyak yaitu $4,6 \times 10^{5} \mathrm{koloni} / \mathrm{ml}$.

\section{DAFTAR PUSTAKA}

Entjang, 2003, Mikrobiologi dan Parasitologi, PT Citra Aditya Bakti, Bandung.

Harmita dan Radji, M., 2008, Buku Ajar Analisis Hayati, EGC, Jakarta, http://googlebook.com diakses pada tanggal 26 Januari 2014.

Hiranya, M., Herijulianti, E., Nurjannah, N., 2011, Ilmu Pencegahan Penyakit Jaringan Keras dan Jaringan Pendukung Gigi, EGC, Jakarta.

Koerniati, 2006, Perkembangan Perawatan Gigi Masa Depan, Andalas University press, Sumatra.

Mardiana, 2013, Daun Ajaib Tumpas Penyakit, Penebar Swadaya, Jakarta.

Nurani, L., 2012, Petunjuk Praktikum Analisis Obat Tradisional, Laboratorium Farmasi Universitas Ahmad Dahlan, Yogyakarta.

Notoatmojo, S., 2010, Metodologi Penelitian Kesehatan, PT Rineka Cipta, Jakarta.
Novel, S., Wulandari, P., Safitri, R., 2010, Praktikum Mikrobiologi Dasar, CV Trans Info Media, Jakarta.

Pelczar, dan Chan, 2008, Dasar-Dasar Mikrobiologi, Universitas Indonesia, Jakarta.

Pitojo, S., 1992, Budidaya Sukun, Kanisius, Yogyakarta.

Pratiwi, D., 2007, Gigi Sehat, PT Kompas Media Nusantara, Jakarta.

Riset Kesehatan Dasar Tahun 2007. httpwww.k4health.orgsitesdefaultfile slaporanNasional\%20Riskesdas\%202 007.pdf diakses pada tanggal 20 Desember 2013

Rizema, S., 2013, Ajaibnya Daun Sukun Berantas Berbagai Penyakit, Flash Books, Yogyakarta.

Sabir, A., 2003, Pemanfaatan flavonoid di bidang kedokteran gigi, Majalah kedokteran gigi edisi khusus temu ilmiah nasional 3, hal. 81- 87, Surabaya, Airlangga University press diakses pada tanggal 18 Mei 2014.

Suryanto, E., dan Wehantouw, F., 2009, Aktivitas Penangkap Radikal Bebas Dari Ekstrak Fenolik Daun Sukun, Vol. 2, No.1 diakses tanggal 17 Mei 2014

Soesanto, 2011, Bahan Ajar Mikrobiologi Kesehatan, Poltekkes Kemenkes Semarang Jurusan Keperawatan gigi, Semarang.

Wardany, K., 2012, Khasiat Istimewa Sukun, Rapha Publishing, Yogyakarta.

Yuwono, T., 2010, Biologi Molekular, Erlangga, Jakarta, http://googlebook.com diakses pada tanggal 18 April 2014. 